\title{
Pengaruh Profesionalisme dan Iklim Kerja terhadap Kinerja Karyawan pada PT. Bank Tabungan Negara Kantor Cabang Malang
}

\author{
Kartono \\ Sekolah Tinggi Ilmu Ekonomi Kertanegara Malang \\ Email. Kartono_putra@stiekma.ac.id
}

\begin{abstract}
Abstrak : Tujuan penelitian ini adalah untuk mengetahui pengaruh profesionalisme dan iklim kerja secara sumultan dan parsial terhadap kinerja karyawan serta pengaruh dominan diantara profesionalisme dan iklim kerja terhadap kinerja karyawan pada PT. Bank Tabungan Negara Kantor Cabang Malang. Populasi dalam penelitian ini adalah seluruh karyawan PT. Bank Tabungan Negara Kantor Cabang Malang yang berjumlah 108 karyawan. Berdasarkan asumsi bahwa populasi berdistribusi normal, maka cara menentukan ukuran sampel dengan rumus slovin, yaitu 53 responden. Hasil penelitian menunjukkan bahwa hipotesis yang menyatakan profesionalisme dan iklim kerja secara simultan berpengaruh signifikan terhadap kinerja karyawan dalam penelitian ini dapat terbukti atau dapat diterima. Kemudian, variabel profesionalisme secara parsial berpengaruh signifikan terhadap kinerja karyawan. Selanjutnya, variabel iklim kerja secara parsial berpengaruh signifikan terhadap kinerja karyawan. Nilai koefisien beta yang distandarisasi variabel iklim kerja lebih besar dibandingkan dengan nilai koefisien beta yang distandarisasi variabel profesionalisme. Hasil tersebut bermakna iklim kerja merupakan variabel yang berpengaruh paling dominan terhadap kinerja karyawan.
\end{abstract}

Kata kunci: Profesionalisme, Iklim Kerja, Kinerja Karyawan

\section{Pendahuluan}

Profesionalisme sangat penting sekali untuk di miliki oleh setiap karyawan bank, selain besar sekali manfaatnya bagi pihak bank, profesionalisme juga dapat membantu dirinya sendiri untuk menjadi pribadi yang lebih baik lagi. Profesionalisme bisa disejajarkan dengan isme-isme (baca: paham atau alliran) yang lain. Sedangkan istilah profesional bisa dikonotasikan dengan penganut (orangnya) atau berkaitan dengan sifat, sedangkan bidangnya disebut profesi. Dalam kamus kata-kata serapan asing dalam bahasa indonesia, karangan J.S. Badudu (2003), definisi profesionalisme adalah mutu, kualitas, dan tindak tanduk yang merupakan ciri suatu profesi atau ciri orang yang profesional. Sementara kata profesional sendiri berarti (1) bersifat profesi (2) memiliki keahlian dan keterampilan karena pendidikan dan latihan, (3) beroleh bayaran karena keahliannya itu. Dari definisi di atas dapat disimpulkan bahwa profesionalisme memiliki dua kriteria pokok, yaitu keahlian dan pendapatan (bayaran). Kedua hal itu merupakan satu kesatuan yang saling berhubungan. Artinya seseorang dapat dikatakan memiliki profesionalisme manakala memiliki dua hal pokok tersebut, yaitu keahlian (kompetensi) yang layak sesuai bidang tugasnya dan pendapatan yang layak sesuai kebutuhan hidupnya. Hal itu berlaku pula untuk profesionalisme karyawan bank. 
Profesionalisme merupakan faktor yang sangat penting dalam suatu lembaga atau organisasi. Para karyawan akan bekerja secara profesional apabila Iklim Kerja ikut memberikan dukungan. Para karyawan yang professional akan memperlihatkan kemampuan dan keahliannya, sikap dan displin, minat dan semangat, untuk bekerja terhadap Kinerja yang tinggi. Oleh karena itu karyawan dituntut untuk memiliki kemampuan secara professional dalam melaksanakan tugas-tugasnya sehingga kinerja mereka meningkat. Pada gilirannya para pekerja harus mampu mengembangkan dirinya secara optimal, terutama dalam bidang yang berkaitan langsung dengan peningkatan kinerja. Salah satu hal yang penting dalam pengelolaan tenaga kerja adalah masalah Iklim Kerja. Iklim Kerja merupakan hal yang memiliki keterkaitan yang sangat erat dengan profesionalisme. Iklim kerja yang kondusif merupakan faktor yang tidak dapat diabaikan dalam suatu sistem pengelolaan manajemen di suatu organisasi. Pentingnya iklim kerja yang kondusif selayaknya mendapat perhatian yang serius dari pihak manajemen, karena tugas-tugas akan dapat terselesaikan secara baik apabila tercipta suatu iklim kerja yang mampu menumbuhkan semangat kerja yang tinggi, yang selanjutnya akan mempercepat proses penyelesaian tugas yang menjadi tanggung jawab karyawan (Subanegara, 2004). Iklim kerja yang kondusif akan meningkatkan kinerja staf yang dapat ditunjukkan dengan tingginya retensi petugas. Petugas akan termotivasi untuk melakukan setiap pekerjaan dengan baik. Output berupa tingginya kinerja petugas, produktifitas tinggi merupakan gambaran lingkungan kerja yang telah bersinar sebagai akibat dari pengaruh kepuasan kerja yang tinggi dari suatu organisasi (Luthans, 2006).

Keberhasilan pengelolaan suatu organisasi secara optimal dan profesional akan terlihat dari pencapaian target kerja dari program tersebut. Hasil kerja yang baik dapat dilihat dari beberapa indikator kinerja antara lain: (1) melalui perwujudan kinerja yang tinggi, (2) tingkat stres yang rendah, (3) keinginan staf untuk tetap tinggal dalam suatu organisasi dan tingkat loyalitas yang tinggi terhadap organisasinya (Robbins, 2006). Kinerja yang optimal dapat diperoleh apabila pegawai tersebut semangat dan bergairah dalam melaksanakan pekerjaannya, dan dapat mencapai target yang telah ditentukan, kualitas kerja yang bermutu dan sesuai dengan standar kerja. Peningkatan kinerja para pegawai juga tidak terlepas dari beberapa faktor terkait dari sistem yang ada dalam organisasi tersebut. Sistem organisasi harus mampu menciptakan suatu iklim yang dapat menimbulkan keinginan berprestasi seluruh pegawainya (Prihadi, 2004). Dari beberapa ulasan dan teori yang disebutkan di atas dapat disimpulkan keberhasilan suatu organisasi dalam mewujudkan kinerja yang optimal sangat ditentukan oleh profesionalisme karyawan dan penciptaan iklim kerja yang kondusif. Disinilah diperlukan profesionalisme dan Iklim Kerja yang berperan di berbagai strata untuk mengerahkan kemampuan dirinya dengan motivasi kerja menggerakkan orang-orang atau bawahannya serta sumber daya yang ada secara rasional agar Iklim Kerja mencapai tujuan dan sasaran yang telah ditetapkan. Profesionalisme dan Iklim Kerja juga harus mampu mengakomodasikan perubahan-perubahan baik yang berskala domestic maupun global akibat dinamika masyarakat yang semakin berkembang.

Profesionalisme dan Iklim Kerja juga memiliki visi dan misi jauh kedepan. Akibatnya orang-orang yang ada di dalam organisasi tersebut proaktif, antisipatif khususnya pada era informasi sekarang ini yang penuh tantangan, peluang, dan persaingan. Kualitas sumber daya manusia yang profesional adalah para karyawan yang dalam bekerja selalu berupaya untuk dapat meningkatkan Iklim Kerja. Berdasarkan uraian di atas, maka peneliti bermaksud menulis tesis dengan judul "Pengaruh Profesionalisme dan Iklim Kerja Terhadap Kinerja Karyawan Pada PT. Bank Tabungan Negara Kantor Cabang Malang“. 


\section{Metode}

A. Jenis Penelitian

Bila dilihat dari data yang dikumpulkan dari sampel atau populasi untuk mewakili seluruh populasi, maka penelitian ini termasuk penelitian survey. Penelitian survey dibatasi pada penelitian yang datanya dikumpulkan dari sampel atas populasi untuk mewakili seluruh populasi. Oleh karena survey ini digunakan untuk menjelaskan hubungan kausal antar variabel-variabel melalui pengujian hipotesis, maka penelitian ini disebut pula penelitian penjelasan. Penelitian ini dapat melihat akibat dari suatu fenomena dan menguji hubungan sebab akibat dari data-data yang tersedia.

B. Populasi Dan Sampel Penelitian

Sebagaimana uraian dimuka, bahwa tujuan penelitian ini adalah diarahkan untuk mendapatkan gambaran tentang aspek kerja yang mempengaruhi kinerja pegawai. Dengan demikian yang menjadi unit analisisnya adalah individu para karyawan PT. Bank Tabungan Negara Kantor Cabang Malang. Populasi dalam penelitian ini adalah seluruh karyawan PT. Bank Tabungan Negara Kantor Cabang Malang yang berjumlah108 karyawan.

Berdasarkan asumsi bahwa populasi berdistribusi normal, maka cara menentukan ukuran sampel dengan rumus slovin, yaitu:

$$
\mathrm{n} \frac{\mathrm{N}}{\mathrm{N}(\mathrm{d})^{2} \quad 1}
$$

Keterangan:

$$
\begin{array}{ll}
\mathrm{n} & =\text { jumlah sampel } \\
\mathrm{N} & =\text { jumlah populasi } \\
\mathrm{d} & =\text { presisi yang digunakan }
\end{array}
$$

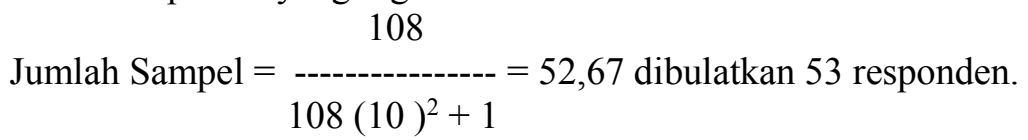

C. Identifikasi Dan Operasional Variabel

Identifikasi masing-masing variabel penelitian adalah sebagai berikut:

Variabel Bebas adalah Profesionalisme $\left(\mathrm{X}_{1}\right)$ dan Iklim Kerja $\left(\mathrm{X}_{2}\right)$. Sedangkan, Variabel terikat adalah Kinerja Karyawan (Y)

D. Sumber Data

Data yang diperlukan untuk menggambarkan fenomena, menguji hipotesis, maupun menjelaskan pengaruh antar variabel terdiri dari dua sumber, antara lain:

a. Data primer, merupakan data yang langsung dikumpulkan dari sumber pertamanya. Data ini diperoleh melalui kuesioner yang disebarkan pada responden dan wawancara langsung dengan responden.

b. Data sekunder, bersumber dari organisasi berupa dokumentasi yang dimiliki oleh PT. Bank Tabungan Negara Kantor Cabang Malang.

E. Teknik Pengumpulan Data

Pengumpulan data dalam penelitian ini dilakukan melalui teknik kuesioner, wawancara dan dokumentasi. Kuesioner adalah suatu daftar pertanyaan yang 
disajikan kepada responden untuk memperoleh data yang berkaitan dengan penelitian. Kuesioner ini dimaksudkan untuk memperoleh data deskriptif dalam menguji hipotesis. Data diperoleh dengan menggunakan kuesioner yang bersifat tertutup yaitu pertanyaan yang dibuat sedemikian rupa sehingga responden dibatasi dalam memberi jawaban pada beberapa altermatif saja atau pada satu jawaban saja (Nasir, 1988). Item skala penilaian ini disusun berdasarkan skala Likert. Skor yang dipakai adalah 5, 4, 3, 2, 1 yang diterapkan secara bervariasi sesuai katagori pertanyaan.

F. Uji Validitas Dan Uji Reliabilitas

Sebelum analisa data dilakukan maka terlebih dahulu dilakukan uji validitas (kesyahihan) dan reliabilitas (kehandalan) instrumen penelitian yang dalam hal ini adalah angket/kuesioner. Instrumen dikatakan baik kalau valid dan reliabel.

G. Metode Analisis Data

Selanjutnya setelah dilakukan uji instrumen (uji validitas dan reliabilitas) dan dinyatakan valid dan reliabel, maka tahap selanjutnya melakukan analisa data. Pada penelitian ini, analisis data dilakukan dengan analisis deskriptif, analisis regresi linear berganda, uji hipotesis, dan selanjutnya akan dilakukan uji model regresi dengan uji asumsi klasik.

\section{Hasil dan Pembahasan}

A.Uji Instrumen

Validitas merupakan ketepatan dan kecermatan suatu alat ukur dalam melakukan fungsi ukurnya. Suatu instrumen dapat dikatakan mempunyai validitas yang tinggi apabila alat tersebut menjalankan fungsi ukurnya, dan memberikan hasil ukur sesuai dengan maksud dilakukannya pengukuran tersebut. Pengujian validitas dalam penelitian ini mempergunakan analisis korelasi product moment, dengan mengkorelasikan skor setiap item dengan skor total sebagai jumlah skor item. Kriteria pengujian validitas adalah Jika probabilitas $<0,05$ atau nilai $r_{\text {hitung }}>r_{\text {tabel }}$ maka butir pertanyaan valid dan sebaliknya jika probabilitas $>0,05$ atau nilai $\mathrm{r}_{\text {hitung }}<\mathrm{r}_{\text {tabel }}$ maka butir pertanyaan tidak valid. Hasil pengujian validitas instrument disajikan di bawah ini.

Tabel 1 Uji Validitas Variabel

\begin{tabular}{|l|l|c|c|c|}
\hline \multicolumn{1}{|c|}{ Variabel } & Item & $\begin{array}{c}\text { Koefisie } \\
\text { n }\end{array}$ & $\begin{array}{c}\text { Signifik } \\
\text { an }\end{array}$ & Ket \\
\hline \multirow{5}{*}{$\begin{array}{l}\text { Profesionalisme } \\
\left(\mathrm{X}_{1}\right)\end{array}$} & 1 & 0.688 & 0.000 & Valid \\
\cline { 2 - 5 } & 2 & 0.873 & 0.000 & Valid \\
\cline { 2 - 5 } & 3 & 0.849 & 0.000 & Valid \\
\cline { 2 - 5 } & 4 & 0.797 & 0.000 & Valid \\
\cline { 2 - 5 } & 5 & 0.873 & 0.000 & Valid \\
\cline { 2 - 5 } & 6 & 0.691 & 0.000 & Valid \\
\cline { 2 - 5 } & 7 & 0.863 & 0.000 & Valid \\
\cline { 2 - 5 } & 8 & 0.855 & 0.000 & Valid \\
\hline Iklim kerja $\left(\mathrm{X}_{2}\right)$ & 1 & 0.827 & 0.000 & Valid \\
\hline
\end{tabular}




\begin{tabular}{|l|l|l|l|l|}
\hline \multirow{5}{*}{} & 2 & 0.885 & 0.000 & Valid \\
\cline { 2 - 5 } & 3 & 0.856 & 0.000 & Valid \\
\cline { 2 - 5 } & 4 & 0.682 & 0.000 & Valid \\
\cline { 2 - 5 } & 5 & 0.653 & 0.000 & Valid \\
\cline { 2 - 5 } & 6 & 0.828 & 0.000 & Valid \\
\cline { 2 - 5 } & 7 & 0.883 & 0.000 & Valid \\
\cline { 2 - 5 } & 8 & 0.857 & 0.000 & Valid \\
\cline { 2 - 5 } & 9 & 0.693 & 0.000 & Valid \\
\hline \multirow{4}{*}{ Kinerja Karyawan } & 1 & 0.636 & 0.000 & Valid \\
\cline { 2 - 5 } & 2 & 0.936 & 0.000 & Valid \\
\cline { 2 - 5 } & 3 & 0.949 & 0.000 & Valid \\
\cline { 2 - 5 } & 4 & 0.930 & 0.000 & Valid \\
\cline { 2 - 5 } & 5 & 0.931 & 0.000 & Valid \\
\cline { 2 - 5 } & 6 & 0.951 & 0.000 & Valid \\
\cline { 2 - 5 } & 7 & 0.602 & 0.000 & Valid \\
\cline { 2 - 5 } & 8 & 0.921 & 0.000 & Valid \\
\cline { 2 - 5 } & 9 & 0.949 & 0.000 & Valid \\
\cline { 2 - 5 } & 10 & 0.930 & 0.000 & Valid \\
\cline { 2 - 5 } & 11 & 0.907 & 0.000 & Valid \\
\cline { 2 - 5 } & 12 & 0.934 & 0.000 & Valid \\
\hline
\end{tabular}

Sumber: Data Primer diolah 2017

Dari tabel di atas diketahui bahwa nilai Sig. (2-tiled) untuk semua ítem variabel $\mathrm{X}_{1}, \mathrm{X}_{2}$, dan variabel $\mathrm{Y}$ berada dibawah 0.05 . Hal ini dapat dikatakan bahwa semua ítem pada variabel tersebut valid.

Reliabilitas menunjukkan sejauh mana hasil pengukuran tetap konsisten bila dilakukan pengukuran dua kali atau lebih terhadap gejala yang sama. Uji reliabilitas dilakukan dengan menggunakan formula Alpha Cornbach dengan taraf nyata 5\%. Dengam kriteria bilamana koefisien reliabilitasnya mencapai 0.60 (Nurgiyantoro, 2009) maka item tersebut dinyatakan reliabel. Hasil uji reliabilitas masing-masing variabel dapat dilihat pada tabel di bawah ini. Ada juga pendapat lain yaitu dilakukan pada taraf signifikansi 0.05 , artinya instrumen dapat dikatakan reliabel bila nilai alpha lebih besar dari 0.6 (Priyatno, 2008).

Tabel 2 Uji Reliabilitas Variabel

\begin{tabular}{|l|c|c|}
\hline \multicolumn{1}{|c|}{ Variabel } & Alpha & $\begin{array}{c}\text { Keteranga } \\
\mathbf{n}\end{array}$ \\
\hline $\begin{array}{l}\text { Profesionalisme } \\
\left(\mathrm{X}_{1}\right)\end{array}$ & 0.924 & Reliabel \\
\hline Iklim kerja $\left(\mathrm{X}_{2}\right)$ & 0.929 & Reliabel \\
\hline $\begin{array}{l}\text { Kinerja } \\
\text { Karyawan }(\mathrm{Y})\end{array}$ & 0.975 & Reliabel \\
\hline
\end{tabular}

Sumber: Data Primer diolah 2017 
Pengujian reliabilitas instrumen dilakukan pada item pertanyaan yang sudah valid. Instrumen dinyatakan reliabel jika nilai reliabilitas yang diperoleh lebih besar dari 0.6. Hasil uji reliabilitas yang disajikan pada tabel di atas menunjukkan bahwa nilai koefisien reliabilitas variabel $\mathrm{X}_{1}$ sebesar 0.924 , nilai koefisien reliabilitas variabel $\mathrm{X}_{2}$ sebesar 0.929, nilai koefisien reliabilitas variabel Y sebesar 0.975 , yang kesemuanya lebih besar dari 0.6 sehingga instrumen yang digunakan dinyatakan reliabel.

2) Statistik Deskriptif

Berdasarkan jumlah total skor-jawaban responden atas indikator-indikator profesionalisme, maka selanjutnya dilakukan akumulasi skor jawaban responden. Hasil perhitungan di atas menunjukkan bahwa profesionalisme masuk ke dalam kriteria sedang, hal ini dapat dilihat dari skor rata-rata yang dihasilkan sebesar 3.01 dan berdasarkan rentang skor rata-rata berada pada interval 2.61- 3.40 yang berarti masuk dalam klasifikasi penilaian sedang. Berdasarkan jumlah total skor-jawaban responden atas indikator-indikator iklim kerja, maka selanjutnya dilakukan akumulasi skor jawaban responden. Hasil perhitungan di atas menunjukkan bahwa iklim kerja masuk ke dalam kriteria tinggi, hal ini dapat dilihat dari skor rata-rata yang dihasilkan sebesar 3.61 dan berdasarkan rentang skor rata-rata berada pada interval 3.41-4.20 yang berarti masuk dalam klasifikasi penilaian tinggi.

Berdasarkan jumlah total skor-jawaban responden atas indikator-indikator kinerja karyawan, maka selanjutnya dilakukan akumulasi skor jawaban responden. Hasil perhitungan di atas menunjukkan bahwa kinerja karyawan masuk ke dalam kriteria tinggi, hal ini dapat dilihat dari skor rata-rata yang dihasilkan sebesar 3.89 dan berdasarkan rentang skor rata-rata berada pada interval 3.41-4.20 yang berarti masuk dalam klasifikasi penilaian tinggi.

3) Analisis Regresi Linear Berganda

Analisis data yang digunakan dalam penelitian yaitu analisis analisis regresi linier berganda. Adapun hasil analisis regresi linier berganda disajikan pada tabel sebagai berikut:

Tabel 3 Analisis Regresi Linear Berganda

\begin{tabular}{|c|c|c|c|c|c|c|}
\hline \multicolumn{7}{|c|}{ Coefficients $^{\mathbf{a}}$} \\
\hline & & \multicolumn{2}{|c|}{$\begin{array}{c}\text { Unstandardized } \\
\text { Coefficients }\end{array}$} & \multirow{2}{*}{\begin{tabular}{|c|}
$\begin{array}{c}\text { Standardize } \\
\mathrm{d} \\
\text { Coefficients }\end{array}$ \\
Beta \\
\end{tabular}} & \multirow[b]{2}{*}{$\mathrm{t}$} & \multirow[b]{2}{*}{ Sig. } \\
\hline \multicolumn{2}{|c|}{ Model } & B & Std. Error & & & \\
\hline \multirow[t]{3}{*}{1} & (Constant) & -1.365 & 7.227 & & -.189 & .851 \\
\hline & $\begin{array}{l}\text { Profesionalis } \\
\text { me }\end{array}$ & .538 & .237 & .223 & 2.269 & .028 \\
\hline & Iklim Kerja & 1.080 & .160 & .661 & 6.740 & .000 \\
\hline
\end{tabular}

Sumber: Data Primer diolah 2017 
Dari hasil analisis regresi linier berganda diperoleh persamaan regresi sebagai berikut:

$$
\begin{array}{lll}
\mathrm{Y} & =\mathrm{a}+\mathrm{b}_{1} \mathrm{X}_{1}+\mathrm{b}_{2} \mathrm{X}_{2}+\mathrm{e} \\
\mathrm{Y} & = & -1.365+0.538 \mathrm{X}_{1}+1.080 \mathrm{X}_{2}+\mathrm{e}
\end{array}
$$

Dari persamaan regresi linier berganda tersebut, akan dijelaskan sebagai berikut: Konstanta (a) diketahui sebesar -1.365 menunjukkan nilai variabel kinerja karyawan jika tidak dipengaruhi variabel bebas yang terdiri dari profesionalisme $\left(\mathrm{X}_{1}\right)$ dan iklim kerja $\left(\mathrm{X}_{2}\right)$ atau dengan kata lain apabila variabel bebas yang terdiri dari profesionalisme $\left(\mathrm{X}_{1}\right)$ dan kotivasi kerja $\left(\mathrm{X}_{2}\right)$ diasumsikan sama dengan nol, maka variabel kinerja karyawan bernilai -1.365 .

Koefisien regresi variabel iklim kerja $\left(b_{1}\right)$ diketahui sebesar 0.538 yang menunjukkan besarnya pengaruh variabel profesionalisme terhadap kinerja karyawan. Hasil koefisien regresi tersebut bermakna bahwa profesionalisme memiliki pengaruh sebesar 0.538 terhadap kinerja karyawan, di mana pengaruhnya positif (searah). Artinya jika diasumsikan skor variabel profesionalisme meningkat sebesar 1, maka akan menyebabkan kinerja karyawan meningkat sebesar 0.538 dengan asumsi variabel bebas lainnya yaitu variabel iklim kerja konstan. Sebaliknya jika diasumsikan skor variabel profesionalisme menurun sebesar 1, maka akan menyebabkan kinerja karyawan menurun sebesar 0.538 dengan asumsi variabel bebas lainnya (variabel iklim kerja) konstan. Hal tersebut mencerminkan bahwa semakin baik profesionalisme karyawan PT. Bank Tabungan Negara Kantor Cabang Malang, maka akan menyebabkan semakin tinggi kinerja karyawannya, dan sebaliknya jika profesionalisme tidak sebagaimana mestinya, maka akan menyebabkan kinerja karyawan menurun.

Koefisien regresi variabel kompensasi $\left(b_{2}\right)$ diketahui sebesar 1.080 yang menunjukkan besarnya pengaruh variabel iklim kerja terhadap kinerja karyawan. Hasil koefisien regresi tersebut bermakna bahwa iklim kerja memiliki pengaruh sebesar 1.080 terhadap kinerja karyawan, di mana pengaruhnya positif (searah). Artinya jika diasumsikan skor variabel iklim kerja meningkat sebesar 1 , maka akan menyebabkan kinerja karyawan meningkat sebesar 1.080 dengan asumsi variabel bebas lainnya yaitu variabel profesionalisme konstan. Sebaliknya jika diasumsikan skor variabel iklim kerja menurun sebesar 1, maka akan menyebabkan kinerja karyawan menurun sebesar 1.080 dengan asumsi variabel bebas lainnya (variabel profesionalisme) konstan. Hal tersebut mencerminkan bahwa semakin baik iklim kerja karyawan PT. Bank Tabungan Negara Kantor Cabang Malang, maka akan menyebabkan semakin tinggi kinerja karyawan, dan sebaliknya jika iklim kerja tidak seperti yang diharapkan, maka akan menyebabkan kinerja karyawan menurun.

4) Analisis Korelasi (R) Dan Determinasi $\left(\mathrm{R}^{2}\right)$

Tabel 4 Analisis Korelasi (r) dan Determinasi $\left(\mathrm{R}^{2}\right)$

\begin{tabular}{|c|c|c|c|c|}
\hline \multicolumn{5}{|c|}{ Model Summary $^{\mathbf{b}}$} \\
\hline Model & $\mathrm{R}$ & R Square & $\begin{array}{c}\text { Adjusted R } \\
\text { Square }\end{array}$ & $\begin{array}{c}\text { Std. Error of } \\
\text { the Estimate }\end{array}$ \\
\hline
\end{tabular}




\begin{tabular}{|c|c|c|c|c|}
\hline 1 & $.727^{\mathrm{a}}$ & .529 & .510 & 7.408 \\
\hline
\end{tabular}

Sumber: Data Primer diolah 2017

Dari tabel di atas diperoleh nilai koefisien korelasi (r) sebesar 0.727 . Hal ini menunjukkan adanya hubungan positif dan kuat antara variabel profesionalisme dan iklim kerja dengan kinerja karyawan. Hal ini bermakna semakin baik profesionalisme dan iklim kerja di PT. Bank Tabungan Negara Kantor Cabang Malang, maka akan diikuti pula dengan semakin tinggi kinerja karyawan, dan sebaliknya.

Dari perhitungan analisis regresi linier berganda juga diketahui nilai koefisien determinasi R Square $\left(\mathrm{R}^{2}\right)$ yaitu sebesar 0.529. Nilai Adjusted R Square sebesar 0.510 menunjukkan kontribusi atau sumbangan variabel profesionalisme dan iklim kerja terhadap kinerja karyawan. Nilai Adjusted R Square sebesar 0.510 bermakna 51.10\% kinerja karyawan PT. Bank Tabungan Negara Kantor Cabang Malang ditentukan oleh variabel profesionalisme dan iklim kerja, sedangkan lainnya sebesar $48.90 \%$ disebabkan oleh variabel lain yang tidak diteliti, misalnya: motivasi, gaya kepemimpinan, kompensasi dan lain sebagainya.

5) Uji Hipotesis

Hipotesis 1 yang diajukan dalam penelitian ini dinyatakan profesionalisme dan iklim kerja secara simultan berpengaruh signifikan terhadap kinerja karyawan. Untuk membuktikan kebenaran dari uji hipotesis 1 dilakukan dengan melihat hasil Uji-F. Hasil Uji $\mathrm{F}$ (analysis of variance) untuk pengujian hipotesis pertama dapat dilihat pada tabel sebagai berikut:

Tabel 5 Hasil Uji Hipotesis 1

\begin{tabular}{|c|c|c|c|c|c|c|}
\hline \multicolumn{7}{|c|}{ ANOVA $^{b}$} \\
\hline \multicolumn{2}{|c|}{ Model } & $\begin{array}{l}\text { Sum of } \\
\text { Squares }\end{array}$ & $\mathrm{df}$ & $\begin{array}{l}\text { Mean } \\
\text { Square }\end{array}$ & $\mathrm{F}$ & Sig. \\
\hline \multirow[t]{3}{*}{1} & $\begin{array}{l}\text { Regressio } \\
\mathrm{n}\end{array}$ & 3077.918 & 2 & 1538.959 & 28.046 & $.000^{\mathrm{a}}$ \\
\hline & Residual & 2743.629 & 50 & 54.873 & & \\
\hline & Total & 5821.547 & 52 & & & \\
\hline \multicolumn{7}{|c|}{ a. Predictors: (Constant), Iklim Kerja, Profesionalisme } \\
\hline \multicolumn{7}{|c|}{ b. Dependent Variable: Kinerja Karyawan } \\
\hline
\end{tabular}

Sumber: Data Primer diolah 2017

Dari hasil analisis diketahui nilai $\mathrm{F}_{\text {hitung }}$ sebesar 28.046 sedangkan pada tingkat kepercayaan $95 \%(\alpha=5 \%)$ diperoleh nilai $\mathrm{F}_{\text {tabel }}=3.183$ maka $\mathrm{F}_{\text {hitung }}>\mathrm{F}_{\text {tabel }}$ dengan nilai probabilitas $0.000<0.05$, sehingga Ho ditolak dan Ha diterima yang berarti bahwa variabel profesionalisme $\left(\mathrm{X}_{1}\right)$ dan iklim kerja $\left(\mathrm{X}_{2}\right)$ terbukti secara simultan berpengaruh signifikan terhadap kinerja karyawan pada tingkat kesalahan 5\% $(\alpha=5 \%)$. Hal tersebut 
mencerminkan bahwa variabel profesionalisme $\left(\mathrm{X}_{1}\right)$ dan iklim kerja $\left(\mathrm{X}_{2}\right)$ secara bersama-sama (simultan) dapat menjelaskan kinerja karyawan, atau dengan pengertian lain jika pada saat yang sama profesionalisme $\left(\mathrm{X}_{1}\right)$ dan iklim kerja $\left(\mathrm{X}_{2}\right)$ berjalan dengan baik dan efektif, maka akan berpengaruh signifikan (nyata) terhadap kinerja karyawan. Dengan demikian hipotesis yang menyatakan profesionalisme dan iklim kerja secara simultan berpengaruh signifikan terhadap kinerja karyawan dalam penelitian ini dapat terbukti atau dapat diterima.

Hipotesis 2 yang diajukan dalam penelitian ini yaitu dinyatakan profesionalisme dan iklim kerja secara parsial berpengaruh signifikan terhadap kinerja karyawan. Untuk membuktikan kebenaran hipotesis 2 dalam penelitian ini digunakan Uji-t. Kriteria penerimaan hipotesis kedua dalam penelitian ini adalah: Jika $t_{\text {hitung }}>t_{\text {tabel }}$ atau probabilitas $<0,05$, maka hipotesis nol (Ho) ditolak dan hipotesis alternatif (Ha) diterima, artinya secara parsial variabel profesionalisme $\left(\mathrm{X}_{1}\right)$ dan iklim kerja $\left(\mathrm{X}_{2}\right)$ berpengaruh signifikan terhadap kinerja karyawan pada tingkat kesalahan 5\% ( $\alpha=5 \%)$. Sebaliknya, jika $t_{\text {hitung }}<t_{\text {tabel }}$ atau probabilitas $>0,05$, maka hipotesis nol (Ho) diterima dan hipotesis alternatif (Ha) ditolak, artinya secara parsial variabel profesionalisme $\left(\mathrm{X}_{1}\right)$ dan iklim kerja $\left(\mathrm{X}_{2}\right)$ tidak berpengaruh signifikan terhadap kinerja karyawan pada tingkat kesalahan 5\% $(\alpha=5 \%)$. Hasil Uji t dapat dilihat pada tabel sebagai berikut:

Tabel 6 Hasil Uji Hipotesis 2

\begin{tabular}{|c|c|c|c|c|c|c|}
\hline \multicolumn{7}{|c|}{ Coefficients $^{\mathrm{a}}$} \\
\hline \multirow{2}{*}{\multicolumn{2}{|c|}{ Model }} & \multicolumn{2}{|c|}{$\begin{array}{c}\text { Unstandardized } \\
\text { Coefficients }\end{array}$} & \multirow{2}{*}{$\begin{array}{c}\begin{array}{c}\text { Standardize } \\
\mathrm{d} \\
\text { Coefficient } \\
\mathrm{s}\end{array} \\
\\
\text { Beta } \\
\end{array}$} & \multirow[b]{2}{*}{$\mathrm{t}$} & \multirow[b]{2}{*}{ Sig. } \\
\hline & & B & $\begin{array}{l}\text { Std. } \\
\text { Error }\end{array}$ & & & \\
\hline \multirow[t]{3}{*}{1} & (Constant) & -1.365 & 7.227 & & -.189 & .851 \\
\hline & $\begin{array}{l}\text { Profesionalis } \\
\text { me }\end{array}$ & .538 & .237 & .223 & 2.269 & .028 \\
\hline & Iklim Kerja & 1.080 & .160 & .661 & 6.740 & .000 \\
\hline
\end{tabular}

a. Dependent Variable: Kinerja Karyawan

Sumber: Data primer diolah 2017

Dari hasil analisis data sebagaimana disajikan pada tabel di atas, maka akan diuraikan hasil Uji t masing-masing variabel bebas sebagai berikut: Nilai thitung variabel profesionalisme sebesar 2.269 sedangkan nilai tabel diketahui sebesar 2.009 sehingga $t_{\text {hitung }}>\mathrm{t}_{\text {tabel }}$ dengan nilai signifikansi (probabilitas) sebesar $0.028<\alpha=5 \%(0.05)$. Hal ini bermakna bahwa variabel profesionalisme secara parsial berpengaruh signifikan terhadap kinerja karyawan. Nilai thitung variabel iklim kerja sebesar 6.740 sedangkan nilai $t_{\text {tabel }}$ diketahui sebesar 2.009 sehingga $t_{\text {hitung }}>t_{\text {tabel }}$ dengan nilai signifikansi (probabilitas) sebesar $0.000<\alpha=5 \%(0,05)$. Hal ini bermakna bahwa variabel iklim kerja secara parsial berpengaruh signifikan terhadap kinerja karyawan. Hipotesis 3 yang 
diajukan dalam penelitian ini yaitu dinyatakan iklim kerja berpengaruh dominan terhadap kinerja karyawan. Untuk membuktikan kebenaran hipotesis 3 dalam penelitian ini dilakukan dengan membandingkan nilai koefisien beta yang distandarisasi masingmasing variabel bebas. Kriteria pengujian hipotesis ketiga dalam penelitian ini adalah variabel bebas yang memiliki nilai koefisien beta yang distandarisasi $\left(\beta_{\mathrm{i}}\right)$ paling besar maka dinyatakan sebagai variabel yang berpengaruh dominan terhadap variabel terikat.

Dari hasil analisis diketahui nilai koefisien beta yang distandarisasi masingmasing variabel bebas yang terdiri dari profesionalisme $\left(\mathrm{X}_{1}\right)$ dan iklim kerja $\left(\mathrm{X}_{2}\right)$, sebagai berikut:

Tabel 7 Hasil Uji Hipotesis 3

\begin{tabular}{|c|c|c|c|c|c|c|}
\hline \multicolumn{7}{|c|}{ Coefficients $^{\mathrm{a}}$} \\
\hline \multirow{2}{*}{\multicolumn{2}{|c|}{ Model }} & \multicolumn{2}{|c|}{$\begin{array}{c}\text { Unstandardized } \\
\text { Coefficients }\end{array}$} & \multirow{2}{*}{\begin{tabular}{|c}
$\begin{array}{c}\text { Standardize } \\
\mathrm{d} \\
\text { Coefficient } \\
\mathrm{s}\end{array}$ \\
\\
Beta
\end{tabular}} & \multirow[b]{2}{*}{$\mathrm{t}$} & \multirow[b]{2}{*}{ Sig. } \\
\hline & & B & $\begin{array}{l}\text { Std. } \\
\text { Error }\end{array}$ & & & \\
\hline \multirow[t]{3}{*}{1} & (Constant) & -1.365 & 7.227 & & -.189 & .851 \\
\hline & $\begin{array}{l}\text { Profesionalis } \\
\text { me }\end{array}$ & .538 & .237 & .223 & 2.269 & .028 \\
\hline & Iklim Kerja & 1.080 & .160 & .661 & 6.740 & .000 \\
\hline
\end{tabular}

Sumber: Data Primer diolah 2017

Dari tabel di atas diketahui nilai koefisien beta yang distandarisasi variabel iklim kerja sebesar 0.661 sedangkan nilai koefisien beta yang distandarisasi variabel profesionalisme sebesar 0.223 . Hal ini menunjukkan bahwa nilai koefisien beta yang distandarisasi variabel iklim kerja lebih besar dibandingkan dengan nilai koefisien beta yang distandarisasi variabel profesionalisme. Hasil tersebut bermakna iklim kerja merupakan variabel yang berpengaruh paling dominan terhadap kinerja karyawan.

\section{B. Pembahasan}

Hasil penelitian menunjukkan bahwa profesionalisme masuk ke dalam kriteria sedang, hal ini dapat dilihat dari skor rata-rata yang dihasilkan sebesar 3.01 dan berdasarkan rentang skor rata-rata berada pada interval 2.61- 3.40 yang berarti masuk dalam klasifikasi penilaian sedang. Disamping itu berdasarkan uji-t diketahui bahwa variabel profesionalisme secara parsial berpengaruh signifikan terhadap kinerja karyawan. Hasil penelitian tersebut sesuai dengan hasil penelitian Cahyani (2007) dan Cahyasumirat (2006). Hasil penelitian mereka menyebutkan bahwa profesionalisme berpengaruh positif dan signifikan terhadap kinerja karyawan. Pengaruh yang positif ini menunjukkan adanya pengaruh yang searah antara profesionalisme dengan kinerja karyawan, atau dengan kata lain dengan profesionalisme baik maka kinerja karyawan tinggi. Profesionalisme 
berpengaruh signifikan terhadap kinerja karyawan. Pengaruh yang signifikan menunjukkan bahwa gaya profesionalisme berpengaruh nyata (berarti) terhadap kinerja karyawan. Kinerja karyawan PT. Bank Tabungan Negara Kantor Cabang Malang tinggi, hal ini menunjukkan bahwa pekerjaan dan hasil kerja yang dilakukan karyawan baik. Dengan profesionalisme yang memiliki kompetensi akan mampu menyelesaikan suatu pekerjaan yang optimal. Kemampuan, pengetahuan, keahlian serta keterampilan yang dimilikinya akan membantu pencapaian hasil yang optimal. Sebagaimana disampaikan oleh Tjiptoherijanto (2000) yang mengatakan bahwa profesionalisme terlihat dari kompetensi yang terwujud pada kapasitas yang dimiliki seseorang yang meliputi keahlian dan keterampilan (skill), pengetahuan (knowledge) dan perilaku (behavior).

$\begin{array}{cccccc}\text { Profesionalisme } & \text { karyawan dibangun melalui penguasaan kompetensi- } \\ \text { kompetensi yang } & \text { secara nyata diperlukan dalam menyelesaikan }\end{array}$ pekerjaan. Purwanto (2000) menyatakan bahwa kompetensi-kompetensi penting bagi para karyawan adalah kompetensi dibidang substansi, bidang komunikasi dan bidang hubungan serta pelayanan atau pengabdian masyarakat. Kemudian Surachmad (2003) yang dikutip oleh Asnawir (2001) mengemukakan bahwa Profesionalisme karyawan/karyawan itu harus memiliki:

1) Kompetensi Profesional, yaitu memiliki pengetahuan yang luas mengenai bidang tugas yang diemban.

2) Kompetensi Personal, yaitu memiliki sikap dan kepribadian yang mantap.

3) Kompetensi Sosial, yaitu menunjukkan kemampuan berkomunikasi dengan orang lain atau masyarakat.

4) Kemampuan dalam memberikan layanan kemanusiaan yaitu mengutamakan nilai kemanusiaan daripada benda atau material.

\section{Pengaruh Iklim kerja Terhadap Kinerja Karyawan}

Hasil penelitian menunjukkan bahwa iklim kerja masuk ke dalam kriteria tinggi, hal ini dapat dilihat dari skor rata-rata yang dihasilkan sebesar 3.61 dan berdasarkan rentang skor rata-rata berada pada interval 3.41-4.20 yang berarti masuk dalam klasifikasi penilaian tinggi. Disamping itu berdasarkan uji-t diketahui bahwa variabel iklim kerja secara parsial berpengaruh signifikan terhadap kinerja karyawan. Hasil penelitian tersebut sesuai dengan hasil penelitian Multi dan Suryalena (2013), Siagian (2013) dan Sambas (2008). Hasil penelitiannya menyebutkan bahwa iklim kerja mempengaruhi kinerja karyawan. Berdasarkan hasil koefisien korelasi antara iklim kerja dengan kinerja karyawan, hubungan anan tara kedua variabel positif. Dan berdasarkan hasil uji signifikan didapat $\mathrm{t}$ hitung $>\mathrm{t}$ tabel yang berarti terdapat hubungan yang positif dan signifikan anatara iklim kerja dengan kinerja karyawan. Sedangkan berdasarkan hasil determinasi bahwa kinerja karyawan dipengaruhi oleh iklim kerja.

Iklim organisasi adalah suatu karakteristik yang membedakan suatu organisasi dengan organisasi lainnya, mempengaruhi individu-individu didalamnya, serta secara relatif bertahan dalam jangka waktu tertentu (Hakim, 2006). Definisi lain iklim organisasi adalah lingkungan psikologis organisasi yang mempunyai kondisi berbeda antara tempat 
yang satu dengan yang lainnya. Iklim organisasi merupakan persepsi tentang kebijakan, praktik-praktik dan prosedur-prosedur organisasional yang dirasakan dan diterima oleh individu-individu dalam organisasi. Individu-individu menganggap atribut-atribut organisasi sebagai pengakuan disebut sebagai iklim psikologikal. Ketika penilaian ini dirasakan dan diterima oleh sebagian besar orang dalam tempat kerja, hal ini disebut sebagai iklim organisasional (Karismawan, 2005). Iklim organisasi sebagai sebuah hasil dari tingkah laku anggota-anggota organisasi. Iklim organisasi secara relatif merupakan kualitas lingkungan internal dari organisasi yang dipertahankan dan membedakan organisasi tersebut dengan organisasi lain, meliputi: hasil dari perilaku dan kebijakan anggota organisasi tersebut dengan organisasi lain, sesuatu yang dirasakan dan diterima oleh anggota organisasi lain, dijadikan sebagai dasar dalam menafsirkan sesuatu dan bertindak sebagai sumber tekanan untuk aktifitas yang sebenarnya (Karismawan, 2005).

\section{Kesimpulan dan Saran}

A. Kesimpulan

Berdasarkan hasil penelitia diatas, maka dapat ditarik kesimpulan sebagai berikut :

1. Hasil penelitian menunjukkan bahwa profesionalisme masuk ke dalam kriteria sedang, hal ini dapat dilihat dari skor rata-rata yang dihasilkan sebesar 3.01 dan berdasarkan rentang skor rata-rata berada pada interval 2.61-3.40 yang berarti masuk dalam klasifikasi penilaian sedang.

2. Hasil penelitian menunjukkan bahwa iklim kerja masuk ke dalam kriteria tinggi, hal ini dapat dilihat dari skor rata-rata yang dihasilkan sebesar 3.61 dan berdasarkan rentang skor rata-rata berada pada interval 3.41-4.20 yang berarti masuk dalam klasifikasi penilaian tinggi.

3. Hipotesis yang menyatakan profesionalisme dan iklim kerja secara simultan berpengaruh signifikan terhadap kinerja karyawan dalam penelitian ini dapat terbukti atau dapat diterima.

4. Variabel profesionalisme secara parsial berpengaruh signifikan terhadap kinerja karyawan.

5. Variabel iklim kerja secara parsial berpengaruh signifikan terhadap kinerja karyawan.

6. Nilai koefisien beta yang distandarisasi variabel iklim kerja lebih besar dibandingkan dengan nilai koefisien beta yang distandarisasi variabel profesionalisme. Hasil tersebut bermakna iklim kerja merupakan variabel yang berpengaruh paling dominan terhadap kinerja karyawan.

B. Saran

Saran-saran yang dapat dikemukakan dari hasil penelitian ini adalah sebagai berikut:

1. Agar dapat memenuhi standar profesional karyawan untuk menunjang tercapainya kinerja yang optimal, maka dapat dimungkinkan karyawan perlu terus meningkatkan kemampuan dan keterampilannya melalui berbagai pelatihan, seminar ataupun workshop, baik yang diselenggarakan oleh pihak internal bank maupun oleh pihak eksternal seperti Perguruan Tinggi Negeri atau 
Swasta dan lembaga-lembaga lain yang kompeten dan memiliki komitmen pada peningkatan kualitas profesional karyawan.

2. Bagi pimpinan PT. Bank Tabungan Negara Kantor Cabang Malang, sebaiknya berusaha selalu menjaga dan meningkatkan Iklim Kelja kepada para karyawannya.

3. Masih banyak faktor-faktor lain yang mempengaruhi Kinerja pada PT. Bank Tabungan Negara Kantor Cabang Malang. Oleh karena itu bagi peneliti berikutnya sebaiknya meneliti faktor-faktor lain di luar model penelitian ini.

\section{Daftar Pustaka}

Adams Chris. 2003. Privacy and Security Issues-Building Custom Trust,

Hot banana software Inc. journal.

Buletin Hukum Perbankan, Agustus 2006, volume 4 nomor 2

Bressan Stephane. 2003. Mengembangkan Electronic Commerce di Indonesia : Aspek Teknologi, Bisnis, dan Hukum, Universiitas Gajah Mada, Yogyakarta.

Carlos Flavian and Miguel Guinaliu, 2006, Consumer Trust, Preceaved Security and Privacy Policy, Emerald: no : 0263-5577, Industrial Management and Data System Journal.

Celuch, K., Goodwin, S., \& Taylor, S. A., 2005, Understanding Small Scale Industrial User Internet Purchase and Information Management Intention: A Test of Two Attitude Models, Industrial Marketing Management Journal.

Che Hussin R., Mahadi Bahari, Dahlan. 2002. Privasi di dalam E-Dagang : Suatu Kajian, Universitas Tekhnologi Malaysia.

Ghozali Imam, 2005, Aplikasi Analisis Multivariate dengan SPSS, edisi ke-3, Badan Penerbit Universitas Diponegoro, Semarang.

Graifhan Ramadhani, 2003, Modul Pengenalan Internet, http://dhani.singcat.com.

Gurvinder S. Shergill \& Zhaobin Chen. 2005. Web-Based Shopping: Consumers' Attitudes towards Online Shopping in Newzealand, Journal of electrinoc commerce research, vol. 6, no2.

Http.www.2600.com. Diakses 10 Februari 2007

Http.www.Forrester.com. Diakses 18 Maret 2007

Http.www.Internetworldstats.com. Diakses 18 Maret 2007

Http.www.etcnewmedia.com. Diakses 20 Maret 2007

Ibrahim, 2005, Analisa Proteksi dan Teknik Keamanan Sistem Informasi ; PT. Asuransi Maju Bersama, Universitas Indonesia, Jakarta.

James A. O'Brien, 2002, Management Information System; Managing Information, Technology in the E-Business Interprise, Mc. Graw-Hil, Fifth edition.

James Engel F., Blackwell Roger D. and Winiard Paul. 1994. Perilaku Konsumen, Binarupa Aksara, Jakarta.

J.K. Shim, Qureshi, Siegel J. and Siegel R. 2000. The International Hand Book Of Electronic Commerce, Glenlake Publishing company, India.

Maholtra Naresh K., 2005, Riset Pemasaran Pendekatan Terapan, PT Indeks Kelompok Gramedia. Jakarta.

Mursito Danan, Sirait R. dan Wardana. 2005, Pendekatan Hukum untuk Keamanan Dunia Cyber serta Urgensl Cyber Law bagi Indonesia, Universitas Indonesia, Jakarta. 
O'Cass, A. and Fenech, T. (2003), “Webretailing adoption: exploring the nature of internet users web retailing behaviour", Journal of Retailing and Consumer Services, Vol. 10, pp. 81-94.

Rahardjo Budi, 2005, Keamanan Sistem Informasi Berbasis Internet, PT Insan Infonesia, Bandung.

Raymond and Lee Matthew. 1997, Trust in E-Commerce; Exploring the Antecedent Factors, Dep. Of information system journal, City Univesity of Hongkong.

Sekaran Uma. 2006. Research Methods For Business; Metodologi Penelitian untuk Bisnis, Buku1 Edisi4, Salemba Empat, Jakarta.

Sekaran Uma. 2006. Research Methods For Business; Metodologi Penelitian untuk Bisnis, Buku2 Edisi4, Salemba Empat, Jakarta.

Shalhoub Karake, 2006, Trust, Privacy, and Security in Electronic Business: the case of GCC countries, Emerald: International Management \& Computer Security Journal, no. 0968-5227. US.

Santoso Singgih, 2004, SPSS Statistik Multivariat, PT Gramedia Jakarta.

Solomon Michael R., 1999, Consumer Behavior, Forth Edition, A Simon \& Schuster Company. New Jersey.

Sudjana, 1992, Teknik Analisis Regresi dan Korelasi, Edisi ke-3, Penerbit Tarsito, Bandung.

Sugiyono, 2005, Metode Penelitian Bisnis, Alpabeta, Bandung

Suyanto M. 2003, Strategi Periklanan Pada E-Commerce Perusahaan Top Dunia, Andi Offset, Yogyakarta.

Schiffinan LG dan LL Kanuk, 1994, Consumer Behavior, Prentice Hall International, London. Turban. 2002, Information technology for management, John wiley \& Sons Inc. $3^{\text {th }}$ edition.

Thomas J. Kueglen, 2000, Web Advertising and Marketing: Make the Web Work for You, A Devision of Prima Publishing, Third Edition

Udo Godwin J., 2001, Privacy and Security Concerns as Major Barriers for E-Commerce: a Survey Study, Emerald: Information Management and computer security journal, no. 165-174.

Umar Husain, 2005, Riset Pemasaran \& Perilaku Konsumen, PT SUN, Jakarta

Ustadiyanto Riyeke, 2002, Framework E-Commerce, Andi Offset, Yogyakarta.

UU No.8 tahun 1999 tentang perindungan konsumen, Republik Indonesia.

Warta Ekonomi. Maret 2001, No. 9, 5

Zhang Ping and $\mathrm{Na}$ li, 2002, Consumer online shopping attitude and behavior: an assessment of research, Eighth America converence on information system Journal. 